\title{
Histopathological evaluation of latex of Bellaco-Caspi, Himatanthus sucuuba (Spruce) Woodson on wound healing effect in BALB/C mice
}

\author{
Lisbeth Lucia Calero-Armijos ${ }^{1}$ (D), Oscar Herrera-Calderon² (D), Jorge Luis Arroyo-Acevedo3 (D), Juan Pedro Rojas-Armas (iD,
} Renán Dilton Hañari-Quispe ${ }^{4}$ id and Linder Figueroa-Salvador ${ }^{5}$ iD

1. Section of Postgraduate, Universidad Nacional Mayor de San Marcos, Lima 15001, Peru; 2. Department of Pharmacology, Bromatology and Toxicology, Faculty de Pharmacy and Biochemistry, Universidad Nacional Mayor de San Marcos, Lima 15001, Peru; 3. Department of Dynamic Sciences, Faculty of Medicine, Universidad Nacional Mayor de San Marcos, Lima 15001, Peru; 4. Laboratory of Pathology Clinic, Faculty of Veterinary Medicine and Zootechnics, Universidad Nacional del Altiplano, Puno 21001, Peru; 5. School of Medicine, Faculty of Health Sciences, Universidad Peruana de Ciencias Aplicadas, Lima, Peru.

Corresponding author: Oscar Herrera-Calderon, e-mail: oherreraca@unmsm.edu.pe Co-authors: LLC: lisluc21@gmail.com, JLA: jlarroyoa@gmail.com, JPR: jprojasarmas@yahoo.com, RDH: rhanari@unap.edu.pe, LF: linderfyb@yahoo.com

Received: 16-03-2020, Accepted: 23-04-2020, Published online: 10-06-2020

doi: www.doi.org/10.14202/vetworld.2020.1045-1049 How to cite this article: Calero-Armijos LL, Herrera-Calderon O, Arroyo-Acevedo JL, Rojas-Armas JP, Hañari-Quispe RD, Figueroa-Salvador L (2020) Histopathological evaluation of latex of Bellaco-Caspi, Himatanthus sucuuba (Spruce) Woodson on wound healing effect in BALB/C mice, Veterinary World, 13(6): 1045-1049.

\begin{abstract}
Background and Aim: Himatanthus sucuuba (Spruce) Woodson (Apocynaceae) is a medicinal plant known as "BellacoCaspi" widely distributed in Loreto, Peru. In the Peruvian traditional medicine, the latex of the plant is used for the treatment of wounds, inflammation, ulcers, and other ailments. This study aims to evaluate the wound healing effect of the latex of H. sucuuba in BALB/C albino mice.
\end{abstract}

Materials and Methods: Thirty BALB/C male mice were used for wound healing study. In the experimental procedures, wound skin incision was performed at $2.0 \mathrm{~cm}$ in length until subcutaneous on the paravertebral of each animal. Under locally anesthetized with procaine cream, the treatment was conducted. All the mice were divided into three groups, the control group (A), zinc oxide cream (B), and H. sucuuba latex (C). The entire surface of the wound was treated for all the groups, and the treatments were performed daily for 15 days. The experiments were stopped on days 1,7 , and 15 , respectively.

Results: The histopathological study of tissues revealed significant changes in wound healing effect in $H$. sucuuba latex compared to the control and B groups. Consequently, the mice treated with latex showed a significant reduction in epithelialization time and collagen formation. Furthermore, the latex showed a dose-dependent significant reduction of inflammation in the first $24 \mathrm{~h}$ of treatment.

Conclusion: BALB/C mice treated with the latex of $H$. sucuuba possess a wound healing effect that can scientifically prove the traditional use of the plant as a wound healing agent.

Keywords: Apocynaceae, BALB/C mice, latex, pathology, regeneration, wound healing.

\section{Introduction}

The skin is the body's first line of immune defense against physical, chemical, or biological aggression from the external environment [1]. Vasoconstriction is the immediate response to physical aggression, which is caused by prostaglandins and thromboxanes; platelets adhere to exposed collagen and the content is released into granules, while tissue factor activates the coagulation cascade and platelets [2]. All body tissues are capable of healing by regeneration or repair mechanisms $[3,4]$. The process of wound healing is divided into three phases: (a) Inflammation process,

Copyright: Calero-Armijos, et al. Open Access. This article is distributed under the terms of the Creative Commons Attribution 4.0 International License (http://creativecommons.org/licenses/ by/4.0/), which permits unrestricted use, distribution, and reproduction in any medium, provided you give appropriate credit to the original author(s) and the source, provide a link to the Creative Commons license, and indicate if changes were made. The Creative Commons Public Domain Dedication waiver (http:// creativecommons.org/publicdomain/zero/1.0/) applies to the data made available in this article, unless otherwise stated. (b) proliferation, and (c) tissue remodeling. The inflammation phase includes activation of the innate immune system. During this phase, the differentiation of macrophages, monocytes, lymphocytes, and neutrophils infiltrates the wound site and hemostasis [5]. In addition, pathogens and foreign materials are removed from the wound and prevent damage in a localized area. [6]. The proliferative phase is characterized by angiogenesis, collagen deposition, epithelialization, and wound contraction. Angiogenesis involves the growth of new blood vessels from endothelial cells and these are presented in the tissue remodeling phase. Fibroblasts activate collagen and fibronectin to form a new extracellular matrix in fibroplasia and granulation tissue formation [7].

Plants have an important history in wound healing, as they contain a wide variety of botanical compounds [8]. Medicines derived from plants have been the first line of defense to maintain health and fight diseases [9]. These natural agents provide 
tissue healing and renewal through multiple mechanisms [10]. Members of the Apocynaceae family constitute an important source of pharmacological discoveries, as they are used for centuries in ethnic and traditional medicine. Himatanthus sucuuba (Spruce) Woodson is a shrub plant belonging to the Apocynaceae family, which grows in the Amazon regions of Brazil, Peru, and Colombia, which is known as "janaguba," "sucuba," "sucuuba," and "Bellaco-Caspi" [11]. It is used in common medicine as a vermifuge, antitumor, antifungal, analgesic, anti-ulcer, and anti-arthritic [12]. The practice of traditional medicine has stayed in the majority of the Amazon population and $H$. sucuuba is claimed and commonly used for wound healing purposes, which require scientific validation in Peru.

This study aims to evaluate the wound healing effect of the latex of $H$. sucuuba on wounds induced in $\mathrm{BALB} / \mathrm{C}$ mice.

\section{Materials and Methods \\ Ethical approval}

The Ethical Committee at the Faculty of Medicine of the Universidad Nacional Mayor de San Marcos (UNMSM) (Project N 0206-FFB-UPG-2018) reviewed and approved this study.

\section{Study period and Plant material}

Leaves of H. sucuuba (Spruce) Woodson were collected in Iquitos, Department of Loreto, Peru, in December 2018. In the Herbarium of the UNMSM (Lima, Peru), a voucher was deposited with $\mathrm{N}^{\circ}$ 010-USM-2019.

The latex used in this study acquired a break of H. sucuuba stems, which were procured from local farmyard areas of Iquitos. The latex was collected in the morning with a break of stems into a sterile bottle and was stored until further use at $8^{\circ} \mathrm{C}$.

\section{Phytochemical analysis}

For the phytochemical screening of $H$. sucuuba latex, different types of reagents were used; the identification results were presented as positive and negative. The amount of sample taken was $1 \mathrm{~mL}$ of latex with five drops of each reagent [13].

\section{Animals}

In this study, 30 male mice (Mus musculus: BALB/C) aged 12 weeks old and weighing 30-40 g from the Bioterio of the National Institute of Health (INS) were used. All the mice were maintained individually in cages at the Laboratory of Pharmacology, Faculty of Medicine, UNMSM. Pelletized food $\left(\right.$ Ratonina $^{\circledR}$ ) and water were given to ad libitum for 2 weeks, under controlled conditions of temperature $\left(24^{\circ} \mathrm{C}\right)$, relative humidity $(70 \%)$, and with a photoperiod of $12 \mathrm{~h}$ of light cycle and $12 \mathrm{~h}$ of darkness. The research was done in the Bioterio of the Faculty of Medicine in the UNMSM (Lima, Peru).

\section{Experimental design}

Thirty adult mice were divided into three groups. The animal's skin wound was done by means of surgical procedures as explained by Salim et al. [14]. The mice were locally anesthetized by topical cream containing lidocaine $25 \mathrm{mg}$ and procaine $25 \mathrm{mg}$. The control group (A) had no treatment, the standard group (B) applied a commercial cream containing zinc oxide and the latex group (H. sucuuba latex) (C). The study was experimental and the dorsal area of the mouse was shaved with a Depile ${ }^{\circledR}$ cream where a transverse incision was made with an $\mathrm{N}^{\circ} 20$ scalpel on the dorsal-cervical part of $7 \mathrm{~mm}$ in length. The effect of $H$. sucuuba latex was observed in the wound area, and the presence of inflammation and re-epithelialization was pointed as markers of wound healing [15]. The treatments were applied once a day with a swab in sufficient quantity to cover the incision. Furthermore, the respective euthanasia was performed on days 2,7 , and 15 , using an intraperitoneal dose of sodium pentobarbital [16].

\section{Histopathological analysis}

Through surgical precision, a $1 \mathrm{~cm} \times 1 \mathrm{~cm}$ tissue sample was taken from the dorsocervical area after the euthanasia. The fixation of the sample was performed with $10 \%$ neutral formalin buffer, processed by the classical paraffin inclusion technique. The samples were cut to a thickness of 5-8 $\mu \mathrm{m}$, staining with hematoxylin-eosin. Histopathological observations were made by light microscopy at two magnifications: $10 \times$ and $40 \times$. The captured images were allowed to evaluate the re-epithelialization, presence of fibroblasts, granulation tissue, and inflammatory tissue response. For the diagnosis of the healing study, the qualification criteria proposed by Nguyen et al. were used as a reference [17].

\section{Statistical analysis}

The data analyses were expressed by the IBM SPSS Statistics 20.0 (IBM Corp., NY, USA). For the histopathology analysis, the Mann-Whitney U-test was used. $p<0.01$ was considered statistically significant, which is equivalent to a confidence level of $95 \%$.

\section{Results}

Table-1 shows the phytochemical analysis of H. sucuuba latex. The presence of each metabolite was considered as positive or negative by a change of color or any precipitation. More so, free amino groups, phenolic compounds, alkaloids, flavonoids, quinones, saponins, terpenes, and steroids were confirmed.

Table-2 shows the qualification of the histopathological index of the wound on days 1, 7, and 15; for the negative control, the positive control (commercial cream), and $H$. sucuuba latex.

The latex of $H$. sucuuba reduced the time required for epithelialization of the excised wound in mice. A significant $(p<0.001)$ reduction of epithelialization time was observed in mice treated with $100 \%$ $(\mathrm{w} / \mathrm{w})$ latex, as compared to the negative control group (Table-2).

New vessel formation with scattered inflammatory cells and epithelialization was observed in 
latex treated mice in the histopathological evaluation of excised skin for 15 days. In fact, when the latex group is compared to the sections from the positive control group (commercial drug), the latex treated mice exhibited a higher number of collagen fibers

Table-1: Phytochemical constituents of Himatanthus sucuuba latex (Spruce ex Müll. Arg.) Woodson.

\begin{tabular}{lcl}
\hline Test & Results & Phytochemicals \\
\hline Ninhydrin & + & Free amino groups \\
Ferric chloride & + & Phenolic compounds \\
Dragendorff's & + & Alkaloids \\
Mayer & + & Alkaloids \\
Hager & + & Alkaloids \\
Shinoda & - & Flavonoids \\
Bornträger & + & Quinones \\
Foam test & + & Saponins \\
Liebermann-Burchard & + & Terpenes and steroids \\
\hline
\end{tabular}

$+=$ Positive, $-=$ Negative

Table-2: Qualitative analysis of the histological evaluation on wound healing effect of Himatanthus sucuuba latex.

\begin{tabular}{|c|c|c|}
\hline \multicolumn{2}{|c|}{ Treatment } & \multirow{2}{*}{$\begin{array}{l}\text { Results } \\
\text { Inflammation: Severe } \\
\text { Reepithelialization: Mild } \\
\text { Granulation tissue: Thin }\end{array}$} \\
\hline Day 1 & Negative control & \\
\hline & Positive control & Inflammation: Moderate \\
\hline & (commercial & Reepithelialization: Mild \\
\hline & cream) & Granulation tissue: Thin \\
\hline & Himatanthus & Inflammation: Mild \\
\hline & sucuuba latex & $\begin{array}{l}\text { Reepithelialization: Moderate } \\
\text { Granulation tissue: Moderate }\end{array}$ \\
\hline \multirow[t]{7}{*}{ Day 7} & Negative control & Inflammation: Severe \\
\hline & & $\begin{array}{l}\text { Reepithelialization: Mild } \\
\text { Granulation tissue: Thin }\end{array}$ \\
\hline & Positive control & Inflammation: Mild \\
\hline & (commercial & Reepithelialization: Moderate \\
\hline & cream) & Granulation tissue: Moderate \\
\hline & Himatanthus & Inflammation: Mild \\
\hline & sucuuba latex & $\begin{array}{l}\text { Reepithelialization: Complete } \\
\text { Granulation tissue: Moderate }\end{array}$ \\
\hline \multirow[t]{7}{*}{ Day 15} & Negative control & Inflammation: Moderate \\
\hline & & $\begin{array}{l}\text { Reepithelialization: Moderate } \\
\text { Granulation tissue: Thin }\end{array}$ \\
\hline & Positive control & Inflammation: Mild \\
\hline & (commercial & Reepithelialization: Moderate \\
\hline & cream) & Granulation tissue: Moderate \\
\hline & Himatanthus & Inflammation: Mild \\
\hline & sucuuba latex & $\begin{array}{l}\text { Reepithelialization: Complete } \\
\text { Granulation tissue: Abundant }\end{array}$ \\
\hline
\end{tabular}
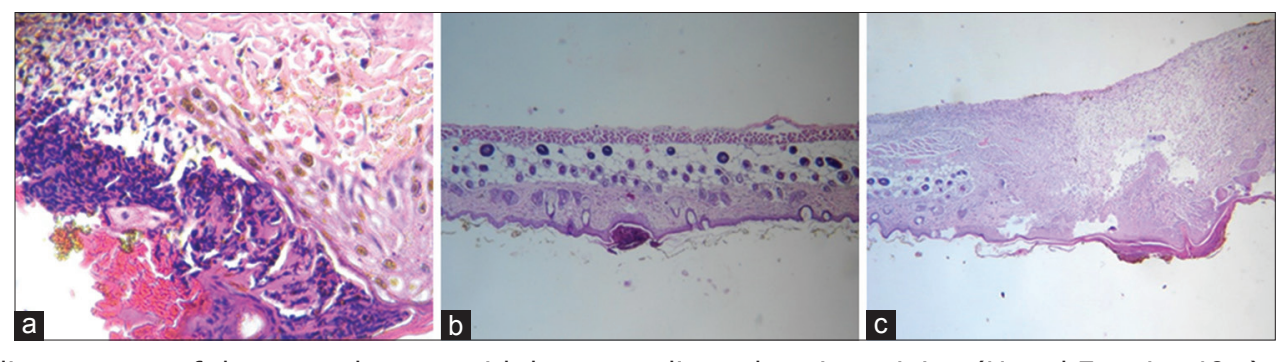

Figure-1: Healing process of the control group with hematoxylin and eosin staining (H and E stain, 40x). (a) Day 1: Loss of epithelium with bleeding and fibrinoid exudate, dense infiltrate of polymorphonuclear leukocytes at the level of the dermoepidermal junction. (b) Day 7: Inflammatory reaction filtered by polymorphonuclear leukocytes and eosinophils, which spread from the superficial dermis to the deepest dermis. (c) Day 15: A large inflammatory reaction to polymorphonuclear leukocytes and eosinophils, which spread from the superficial dermis to the deepest dermis. 


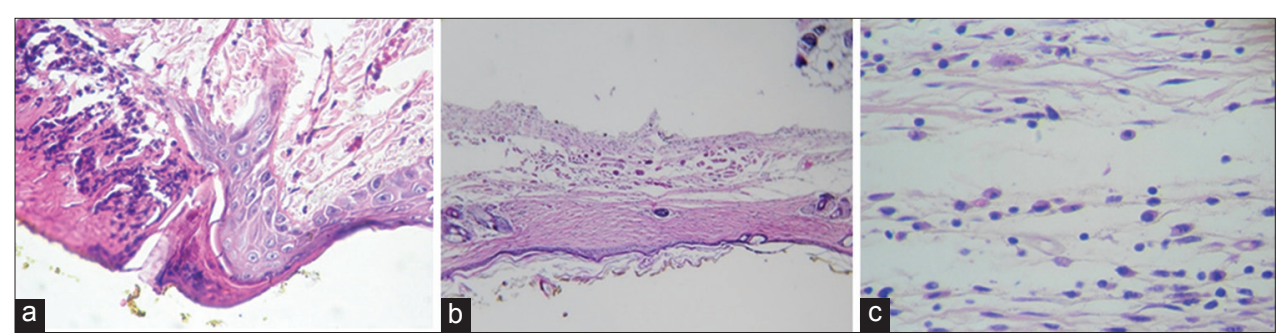

Figure-2: Healing process of the positive control group (cream) with hematoxylin and eosin staining ( $\mathrm{H}$ and $\mathrm{E}$ stain, $40 \times$ ). (a) Day 1: Inflammatory reaction to polymorphonuclear leukocytes, slightly less intense, but also with injury. (b) Day 7: The treated skin appears normal; absence of annexes (hairs and sebaceous glands), which would be atrophy due to the injury performed. (c) Day 15: Preserved skin, decreased skin attachments (hair and glands), and an inflammatory infiltrate of mononuclear cells, such as lymphocytes and macrophages, indicating less intense, chronic inflammation.

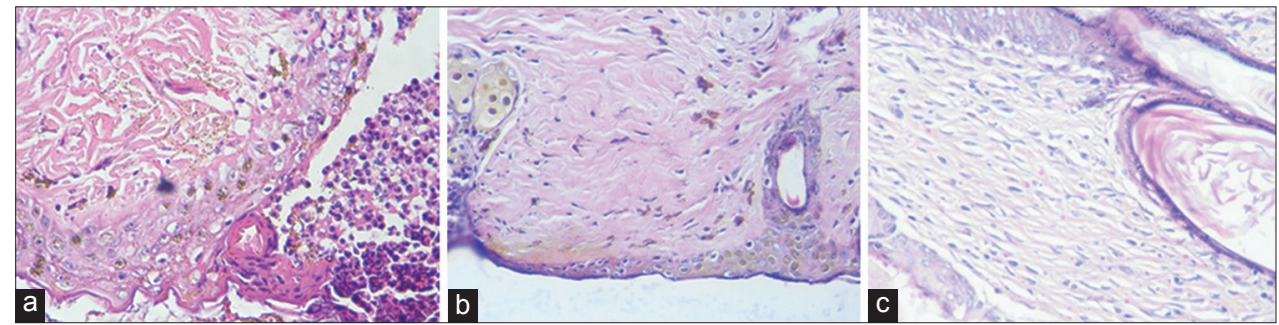

Figure-3: Healing process of the Himatanthus sucuuba latex group ( $\mathrm{H}$ and E stain, 40x). (a) Day 1: Dense inflammatory reaction, but the epithelium is better preserved, two rows of keratinocytes are observed below the superficial infiltrate. Less severe inflammation in the deep dermis. (b) Day 7: An area with fewer adnexa (hairs and sebaceous glands) than in the rest of the skin, and a little more collagen (fibers or thicker). The treated skin appears normal. (c) Day 15: The skin is within normal limits. There is no scar, which would be a fibrous area, with a decrease in skin attachments.

preserved skin, while the control group decreased its skin attachments (hair and glands), and an infiltrate of mononuclear cells, such as lymphocytes and macrophages, which indicate less intensity and damage in the chronic inflammation. de Miranda et al. [23] determined the hexane fraction of $H$. sucuuba inhibited in the edema formation by $35.9 \%$ at a dose of 200 $\mathrm{mg} / \mathrm{kg}$ (p.o.). These results indicate a greater advantage in wound healing of the latex in relation to the positive control.

In addition, the proliferative phase is characterized by angiogenesis, collagen deposition, epithelialization, and wound contraction. Angiogenesis involves the growth of new blood vessels from endothelial cells. Fibroblasts activate collagen and fibronectin to form a new extracellular matrix in fibroplasia and granulation tissue formation [24]. In another report, latex of $H$. sucuuba increased tumor nuclear factor- $\alpha$, nitric oxide, and decreased transforming growth factor- $\beta$ production in macrophages which could be involved in its wound healing mechanism [25]. More so, macrophages are the critical key in the wound healing process and provide a useful therapeutic target for wound healing disorders in aging and diabetes, or excessive wound healing in fibrosis [26,27].

There are no toxic, abortive, or birth defects reported in latex of H. sucuuba. However, it is necessary to establish its toxic dose or concentrations in the future.

\section{Conclusion}

This study has shown that $H$. sucuuba latex has properties that promote a wound healing and anti-inflammatory effect on BALB/C mice; therefore, further research on latex derivatives could lead to its application as a treatment for post-surgical wounds.

\section{Authors' Contributions}

LLC and $\mathrm{OH}$ conceived the study designed. JLA and LLC performed the experiment. $\mathrm{OH}$ and RDH analyzed the data. LF, JPR, and $\mathrm{OH}$ drafted and revised the manuscript. All authors read and approved the final manuscript.

\section{Acknowledgments}

The authors are thankful to Universidad Nacional Mayor de San Marcos, Peru for providing necessary facilities for this study. This research did not receive any specific grant from funding agencies in the public, commercial, or not-for-profit sectors.

\section{Competing Interests}

The authors declare that they have no competing interests.

\section{Publisher's Note}

Veterinary World remains neutral with regard to jurisdictional claims in published institutional affiliation.

\section{References}

1. Rodrigues, M., Kosaric, N., Bonham, C.A. and Gurtner, G.C. (2019) Wound healing: A cellular perspective. Physiol. Rev., 99(1): 665-706.

2. Asadi, S.Y., Parsaei, P., Karimi, M., Ezzati, S., Zamiri, A., Mohammadizadeh, F. and Rafieian-kopaei, M. (2013) Effect of green tea (Camellia sinensis) extract on healing process of surgical wounds in rat. Int. J. Surg., 11(4): 332-337. 
3. Bhaskar, A. and Nithya, V. (2012) Evaluation of the wound-healing activity of Hibiscus rosasinensis L (Malvaceae) in Wistar albino rats. Indian. J. Pharmacol., 44(6): 694.

4. Bhat, P.B., Hegde, S., Upadhya, V., Hegde, G.R., Habbu, P.V. and Mulgund, G.S. (2016), Evaluation of wound healing property of Caesalpinia mimosoides Lam. $J$. Ethnopharmacol., 193: 712-724.

5. Ibrahim, N., Wong, S.K., Mohamed, I.N., Mohamed, N., Chin, K.Y., Ima-Nirwana, S. and Shuid, A.N. (2018) Wound healing properties of selected natural products. Int J. Environ. Res. Public. Health., 15(11): 2360.

6. Lindley, L.E., Stojadinovic, O., Pastar, I. and TomicCanic, M. (2016) Biology and biomarkers for wound healing. Plast. Reconstr. Surg., 138(3 Suppl): 18S-28S.

7. Chen, J., Jayachandran, M., Xu, B. and Yu, Z. (2019) Sea bass (Lateolabrax maculatus) accelerates wound healing: A transition from inflammation to proliferation. $J$. Ethnopharmacol., 236: 263-276.

8. Shedoeva, A., Leavesley, D., Upton, Z. and Fan, C. (2019) Wound healing and the use of medicinal plants. Evid. Based Complement. Alternat. Med., 2019: 2684108.

9. Shah, A. and Amini-Nik, S. (2017) The role of phytochemicals in the inflammatory phase of wound healing. Int. J. Mol. Sci., 18(5): 1068.

10. Klein, K.C. and Guha, S.C. (2014), Cutaneous wound healing: Current concepts and advances in wound care. Indian J. Plast. Surg., 47(3): 303-317.

11. Soares, F.P., Cavalcante, L.F., Romero, N.R. and Bandeira, M.A. (2016) Himatanthus Willd. ex Schult. (Apocynaceae): Review. Pharmacogn. Rev., 10(19): 6-10.

12. Luziatelli, G., Sørensen, M., Theilade, I. and Mølgaard, P. (2010) Asháninka medicinal plants: A case study from the native community of Bajo Quimiriki, Junín, Peru. $J$. Ethnobiol. Ethnomed., 6: 21.

13. Aliyu, R.M., Abubakar, M.B., Kasarawa, A.B., Dabai, Y.U., Lawal, N., Bello, M.B. and Fardami, A.Y. (2015) Efficacy and phytochemical analysis of latex of Calotropis procera against selected dermatophytes. J. Intercult. Ethnopharmacol., 4(4): 314-317.

14. Salim, M.N., Masyitha, D., Harris, A., Balqis, U., Iskandar, C.D., Hambal, M. and Darmawi. (2018) Antiinflammatory activity of Jatropha curcas Linn. latex in cream formulation on CD68 expression in mice skin wound. Vet. World, 11(2): 99-103.

15. Gebrehiwot, M., Asres, K., Bisrat, D., Mazumder, A., Lindemann, P. and Bucar, F. (2015) Evaluation of the wound healing property of Commiphora guidottii Chiov. ex. Guid. BMC Complement. Med. Ther., 15: 282.

16. Dwivedi, D., Dwivedi, M., Malviya, S. and Singh, V. (2016) Evaluation of wound healing, anti-microbial and antioxidant potential of Pongamia pinnata in wistar rats. J. Tradit.
Complement. Med., 7(1): 79-85.

17. Nguyen, V.L., Truong, C.T., Nguyen, B., Vo, T.V., Dao, T.T., Nguyen, V.D., Trinh, D.T., Huynh, H.K. and Bui, C.B. (2017) Anti-inflammatory and wound healing activities of calophyllolide isolated from Calophyllum inophyllum Linn. PLoS One, 12(10): e0185674.

18. Wood, C.A., Lee, K., Vaisberg, A.J., Kingston, D.G.I., Neto, C.C. and Hammond, G.B. (2001) A bioactive spirolactone iridoid and triterpenoids from Himatanthus sucuuba. Chem. Pharm. Bull., 49(11): 1477-1478.

19. Lucetti, D.L., Lucetti, E.C., Bandeira, M.A., Veras, H.N., Silva, A.H., Leal, L.K., Lopes, A.A., Alves, V.C., Silva, G.S., Brito, G.A. and Viana, G.B. (2010) Antiinflammatory effects and possible mechanism of action of lupeol acetate isolated from Himatanthus drasticus (Mart.) Plumel. J. Inflamm. (Lond). 7: 60.

20. Waltenberger, B., Rollinger, J.M., Griesser, U.J., Stuppner, H. and Gelbrich, T. (2011) Plumeridoid C from the Amazonian traditional medicinal plant Himatanthus sucuuba. Acta Crystallogr. C, 67(Pt 10): 409-412.

21. Fakhrudin, N., Waltenberger, B., Cabaravdic, M., Atanasov, A.G., Malainer, C., Schachner, D., Heiss, E.H., Liu, R., Noha, S.M., Grzywacz, A.M., Mihaly-Bison, J., Awad, E.M., Schuster, D., Breuss, J.M., Rollinger, J.M., Bochkov, V., Stuppner, H. and Dirsch, V.M. (2014) Identification of plumericin as a potent new inhibitor of the NF- $\mathrm{KB}$ pathway with anti-inflammatory activity in vitro and in vivo. Br. J. Pharmacol., 171(7): 1676-1686.

22. Saleem, M. (2009) Lupeol, a novel anti-inflammatory and anti-cancer dietary triterpene. Cancer Lett., 285(2): 109-115.

23. de Miranda, A.L.P., Silva, J.R., Rezende, C.M., Neves, J.S., Parrini, S.C., Pinheiro, M.L., Cordeiro, M.C., Tamborini, E. and Pinto, A.C. (2000) Anti-inflammatory and analgesic activities of the latex containing triterpenes from Himatanthus sucuuba. Planta Med, 66(3): 284-286.

24. Landén, N.X., Li, D. and Ståhle, M. (2016) Transition from inflammation to proliferation: A critical step during wound healing. Cell. Mol. Life Sci., 73(20): 3861-3885.

25. Soares, D.C., Andrade, A.L., Delorenzi, J.C., Silva, J.R., Freire-de-Lima, L., Falcão, C.A., Pinto, A.C., RossiBergmann, B. and Saraiva, E.M. (2010) Leishmanicidal activity of Himatanthus sucuuba latex against Leishmania amazonensis. Parasitol. Int., 59(2): 173-177.

26. Pastar, I., Stojadinovic, O., Yin, N.C., Ramirez, H., Nusbaum, A.G., Sawaya, A., Patel, S.B., Khalid, L., Isseroff, R.R. and Tomic-Canic, M. (2014) Epithelialization in wound healing: A comprehensive review. Adv. Wound Care (New Rochelle), 3(7): 445-464.

27. Kim, S.Y. and Nair, M.G. (2019), Macrophages in wound healing: Activation and plasticity. Immunol. Cell Biol., 97(3): 258-267. 